\title{
A Fabry's disease heterozygote with a new mutation: biochemical, ultrastructural, and clinical investigations
}

\author{
L Hasholt, S A Sørensen, A Wandall, E B Andersen, P Arlien-Søborg
}

\begin{abstract}
A Fabry heterozygote with early clinical manifestations of this $\mathbf{X}$ linked disorder is described. Her symptoms, including febrile attacks, arthralgia, abdominal pain, and neurological signs, were characteristic of Fabry's disease hemizygotes. The neurological findings were compatible with a brain stem infarction. The diagnosis was confirmed by the finding of low activities of $\alpha$-galactosidase $A$ $(\alpha-g a l A)$ in plasma, lymphocytes, and cultured fibroblasts, and by the observation of typical lamellar inclusions in the lysosomes of cultured fibroblasts. Increased levels of ceramide trihexoside were also found by TLC of urine sediment.

The family history gave no indication of Fabry's disease in the patient's relatives, and biochemical and ultrastructural investigations of their cells were also normal. Our findings therefore suggest that the defective gene in the heterozygote has resulted from a new mutation.
\end{abstract}

Fabry's disease, which is caused by deficiency of the acid hydrolase $\alpha$-galactosidase A ( $\alpha$-galA), is one of the group of inherited lysosomal disorders. The enzyme, which is coded for by an $\mathrm{X}$ linked gene, catalyses the catabolism of glycosphingolipids; hemizygous Fabry patients accumulate these lipid substrates in their body fluids, and the lipids are deposited in the lysosomes of cells from all tissues. The serious clinical manifestations of the disease, renal complications and heart failure, are mainly the result of substrate accumulation in the vascular endothelium. Carriers of Fabry's disease may have

Institute of Medical Genetics, The Panum Institute, University of Copenhagen, Blegdamsvej 3, DK-2200 Copenhagen $\mathbf{N}$, Denmark.

L Hasholt, S A Sørensen, A Wandall

Department of Neurology, Hvidovre University Hospital, Copenhagen, Denmark.

E B Andersen, P Arlien-Søborg

Correspondence to Dr Hasholt.

Received for publication 8 July 1989.

Revised version accepted for publication 6 October 1989. very low $\alpha$-galA activities as a consequence of Lyonisation, and heterozygotes have been described who have symptoms as severe as those found in hemizygotes. ${ }^{12}$ As would be expected, heterozygotes with a normal phenotype and normal activity of $\alpha$ galA are also known. ${ }^{34}$

In Fabry's disease, as in other $\mathrm{X}$ linked traits, heterozygote identification is thus sometimes difficult, and there may be a problem in discriminating between an inherited case and a new mutation. Clinical, biochemical, and ultrastructural studies of the family presented here indicate that we are in fact dealing with a new mutant allele in the heterozygous proband; her relatives do not seem to have the defective gene. Only a few probable cases of new mutations in hemizygotes have been described ${ }^{5} 6$ and this is the first report of a mutation in a heterozygote with Fabry's disease. It has recently been reported by Desnick et $\mathrm{al}^{7}$ that molecular studies of several unrelated families with Fabry's disease have shown various types of mutation in the $\alpha$-galA gene. The mutation rate is still unknown.

\section{Materials and methods}

MATERIALS

Blood samples were obtained from the proband, her parents, and maternal grandmother. Plasma was withdrawn and lymphocytes were isolated by separation on sodium metrizoate/ficoll (Lymphoprep, Nyegaard \& Co). Fibroblast cultures from these family members and normal controls were grown in Eagles MEM with $20 \%$ pooled human serum under standard conditions. Cultures in early passages were used for the biochemical analyses. Urine was collected from the proband.

\section{BIOCHEMICAL INVESTIGATIONS}

The substrate used for the assays of $\alpha$-galactosidase $(\alpha$-gal) activity was 4-methylumbelliferyl- $\alpha$-Dgalactopyranoside (Sigma). The specific activity was measured in plasma, lymphocytes, and cultured fibroblasts using the method of Desnick et al. ${ }^{8}$ Protein was determined by the method of Lowry et al. ${ }^{9}$ The activity of $\alpha$-gal in fibroblasts was also measured relative to another lysosomal hydrolase, $\beta$-galactosidase 
( $\beta$-gal), by a microfluorometric assay. The substrate used for the assay of $\beta$-gal was $1 \mathrm{mmol} / \mathrm{l} 4 \mathrm{MU}-\beta-\mathrm{D}$ galactopyranoside (Sigma). The method has been described in detail previously ${ }^{10}$; the only modification was the use of $\beta$-galactosidase as the reference enzyme. Briefly, the cells, which had been seeded in the wells of a Terasaki microwell plate (Nunc, Denmark) the day before the assay, were then covered with paraffin oil, and $4 \mu \mathrm{l}$ of the substrate solution was applied to each well under the oil. After incubation for three and a half hours at $37^{\circ} \mathrm{C}$ the process was stopped by the addition of $4 \mu \mathrm{l}$ per well of a glycine buffer, $\mathrm{pH} 10 \cdot 4$. The fluorescence intensities were measured with a Leitz MPV3 microscope fluorometer. As $\alpha$ - $\mathrm{N}$-acetylgalactosaminidase ( $\alpha$-galactosidase $\mathrm{B}$ ) also hydrolyses the artificial substrate, we inhibited this enzyme with $\mathrm{N}$-acetylgalactosamine $(\mathrm{N}$-acg) in order to differentiate the activities of $\alpha$-gal $A$ and $B .{ }^{11}$

Glycolipid detection in urine was performed on 24 hour urine from the patient and the controls essentially as described by Goto et al. ${ }^{12}$ The main difference was that we used $5.0 \times 7.5 \mathrm{~cm}$ HPTLC plates (Merck) for the chromatography.

\section{ELECTRON MICROSCOPY}

The fibroblasts were fixed in situ following the procedure described previously. ${ }^{2}$ The cells from the patient, her mother, and grandmother were fixed at an early passage, 5 or 6 , and the cells from the patient and her mother at passage 14 as well.

\section{CLINICAL TESTS}

Cardiovascular autonomic function was investigated by parasympathetic tests (beat to beat variation during test, deep respiration, and Valsalva manoeuvre $^{1314}$ ), sympathetic tests (change in blood pressure during isometric handgrip $\left.{ }^{13}\right)$, and combined parasympathetic-sympathetic tests (orthostatic blood pressure and heart rate measurements).

\section{Results}

\section{CASE REPORT}

The proband was 18 years old when she was referred to hospital because of attacks of high fever, arthralgia, and abdominal pain. From the age of 16 she had repeated infections of the lungs and upper respiratory tract. The diagnosis of Fabry's disease was suspected by the ophthalmologist after observation of corneal opacities and tortuous retinal vessels. In the following years intermittent abdominal pain, arthralgia, and neurological symptoms have dominated. Attacks of dizziness with and without concomitant fainting appeared over periods of weeks. At the age of 21 years she experienced mild, right sided hemiparesis and initially slight dysarthria. The first attack lasted a few weeks; later accentuation of the right sided hemiparesis lasted only a few days and was very often accompanied by psychogenic aggravation of the symptoms. CT scan of the brain performed three days after the onset of the hemiparesis was normal and EEG was without focal abnormalities in the first week. Additionally, she had a few episodes of double vision and atypical amaurosis fugax. During periods of fainting the EEG, including 24 hour monitoring, occasionally showed spikes and sharp waves and some paroxysms lasting 10 to 30 seconds sometimes with, but mostly without, clinical manifestations. Antiepileptic treatment had no convincing effect. In 1988, at the age of 22, CT scan showed an isolated minor hypodense area in the right side of the brain stem and magnetic resonance imaging (MRI) indicated a distinct area of changed signal in the pons, compatible with a previous brain stem infarction. Because of the frequent fainting, tests of cardiovascular autonomic function were performed in 1984 and in 1988 but showed no abnormalities. Her two brothers, parents, and maternal grandmother have no symptoms of the disease. The maternal grandfather died at 75 years from tuberculosis. Slit lamp investigations of the parents and two brothers showed no abnormalities.

\section{LABORATORY INVESTIGATIONS}

The presence of Fabry's disease in the proband was confirmed by the finding of an increased level of

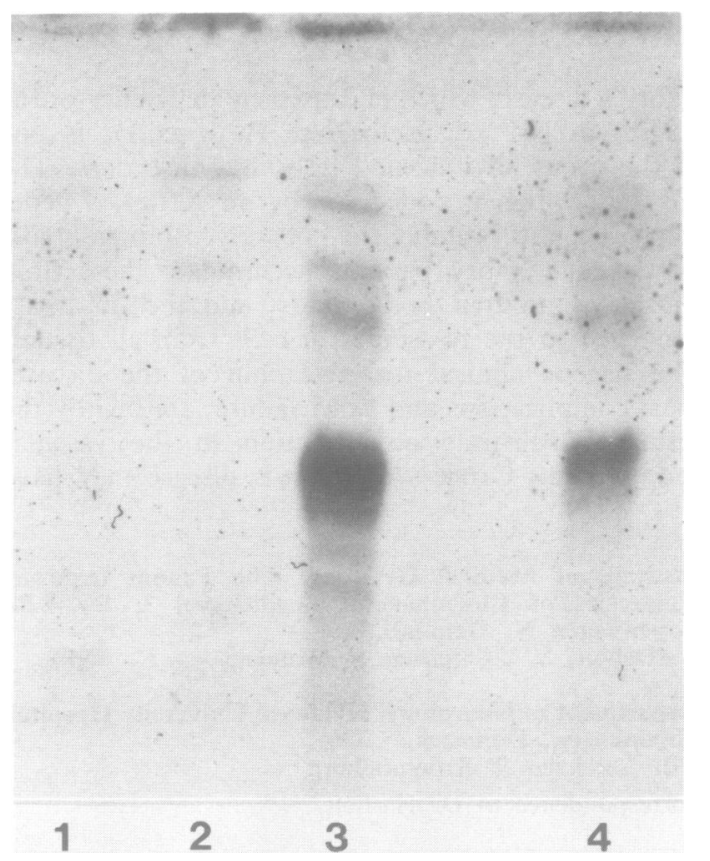

Figure 1 TLC of urine samples from normal subjects (lanes 1 and 2), a Fabry hemizygote (lane 3), and the proband (lane 4). 
Table 1 Specific activities of $\alpha$-galactosidase $A+B$ in plasma and cells from the patient and her relatives.

\begin{tabular}{|c|c|c|c|}
\hline Subjects & Plasma & $\begin{array}{c}\text { Isolated } \\
\text { lymphocytes }\end{array}$ & $\begin{array}{l}\text { Cultured } \\
\text { fibroblasts }\end{array}$ \\
\hline $\begin{array}{l}\text { Proband } \\
\text { Mother } \\
\text { Grandmother } \\
\text { Father } \\
\text { Normal controls }(n=10)\end{array}$ & $\begin{array}{l}2 \cdot 6 \\
9 \cdot 1 \\
13 \cdot 4 \\
15 \cdot 1 \\
7 \cdot 1-15 \cdot 7\end{array}$ & $\begin{array}{l}103 \cdot 2 \\
253 \cdot 2 \\
295 \cdot 2 \\
312 \cdot 1 \\
171 \cdot 0-386 \cdot 0\end{array}$ & $\begin{array}{l}62 \cdot 1 \\
252 \cdot 4 \\
250 \cdot 7 \\
326 \cdot 3 \\
194 \cdot 0-380 \cdot 7\end{array}$ \\
\hline
\end{tabular}

Table 2 Microfluorometric measurements of relative activities of $\alpha$-galactosidase in cultured fibroblasts.

\begin{tabular}{lccc}
\hline & $\alpha$-galA $+B$ & & $\alpha$-galA* \\
\cline { 2 - 2 } Subjects & $\beta$-gal & & $\alpha$-galA+B \\
\hline Proband & 0.024 & & 39 \\
Mother & 0.081 & & 78 \\
Grandmother & 0.103 & & 79 \\
Father & 0.070 & & 72 \\
$\begin{array}{c}\text { Normal controls } \\
(n=9)\end{array}$ & $0.071-0.150$ & $69-98$ \\
$\begin{array}{c}\text { Hemizygotes } \\
(n=4)\end{array}$ & $0.008-0.024$ & $2-15$ \\
$\begin{array}{c}\text { Heterozygotes } \\
(n=4)\end{array}$ & $0.021-0.066$ & $44-89$ \\
\hline
\end{tabular}

${ }^{*}$ The $\alpha$-galA activity was measured after inhibition of $\alpha$-galB with $\mathrm{N}$-acg.

ceramide trihexoside in the urine as shown by TLC (fig 1). A distinct band appeared that was identical to a band found in the sample from a hemizygote, but was absent in the normal controls.

The specific activity of $\alpha$-galactosidase was reduced in plasma, lymphocytes, and cultured fibroblasts from the proband (table 1 ). The activities measured in plasma and the same cell types from the parents and the maternal grandmother were all within the range of normal controls, as were the activities in cultured lymphocytes from her brothers. The diagnosis in the proband was further confirmed by measurement in cultured fibroblasts of the activity of $\alpha$-galactosidase relative to the activity of $\beta$-galactosidase (table 2 ), which showed the same low value as was found in hemizygotes and heterozygotes not related to the family. Furthermore, the activity of $\alpha$-galA, measured after inhibition of $\alpha$-galB with $\mathrm{N}$-acg, was $39 \%$ of the total $\alpha$-gal activity, that is, between the activities of the hemizygotes and the controls. Again the activities in the parents and the grandmother were normal.

Electron microscopical observations of cultured fibroblasts from the proband and her mother and maternal grandmother showed typical lamellar inclusions in the lysosomes of the proband only (fig 2). Since we have previously observed an increase in the number of Fabry inclusions in cells at late passages, cells from the patient and her mother were fixed at a late passage. We observed an increase in the number of inclusions in the cells from the patient, but

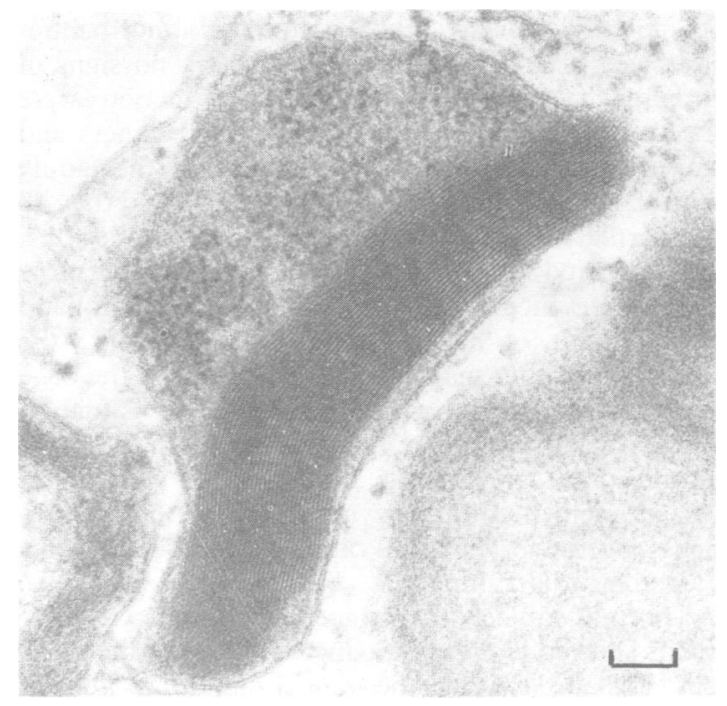

Figure 2 Lamellar inclusions typical of Fabry's disease are seen in the lysosomes in the fibroblasts of the patient. Bar $=0 \cdot 1 \mu \mathrm{m}$.

still no inclusions in the mother's cells. In order to exclude non-paternity, the phenotypes of nine blood group systems and HLA haplotypes were determined for the heterozygote and her parents. The results were consistent with paternity.

\section{Discussion}

The clinical symptoms in this young woman are undoubtedly the result of her heterozygosity for Fabry's disease. She had a clearly lowered $\alpha$-galA activity, ceramide trihexoside was detected in the urine, and lamellar inclusions previously found to be specific for Fabry's disease ${ }^{2}$ were observed in the lysosomes of cultured fibroblasts. Furthermore, slit lamp investigation of the cornea showed the verticillata characteristic of the disease. The biochemical and morphological findings are in accordance with observations in many other heterozygotes. ${ }^{2} 15$ Our patient had symptoms of the disease as early as the age of 16; these symptoms, which frequently occur in young hemizygotes, included intermittent arthralgia and abdominal pain, hemicrania, and febrile attacks. 
Furthermore, she developed neurological signs such as dizziness, hemiparesis, and dysarthria also reported in hemizygotes, but seldom observed in heterozygotes. ${ }^{16}$ Minor EEG abnormalities have previously been described in Fabry patients, ${ }^{17}$ but changes in the brain seen on MRI have only been reported in one case ${ }^{18}$ where lacunar infarcts were found. CT scanning has not, to our knowledge, been applied in any extensive studies on Fabry's disease. Involvement of the autonomic nervous system has been described, ${ }^{19}$ but only slight cardiovascular autonomic abnormalities have been found. ${ }^{20}$ In the present case, no signs of impaired cardiovascular autonomic function were observed in spite of the complaints of dizziness and fainting episodes. No other members of the family showed any symptoms of Fabry's disease, and they all had normal $\alpha$-gal A activities in plasma, lymphocytes, and cultured fibroblasts. We therefore presume that the presence of the abnormal gene in the proband is the result of a new mutation. In theory, the proband's mother may be a hidden carrier of the gene and still show normal $\alpha$-galA activities. This situation could arise from preferential inactivation of the $\mathrm{X}$ chromosome carrying the mutant gene. We therefore supplemented the enzyme studies with measurements of the $\alpha$-gal $/ \beta$-gal ratio as this should give a better discrimination between heterozygotes and normal subjects than the specific activity. ${ }^{21}$ Our results showed that the ratio measured in the mother's cells was also within the range found for normal subjects. Furthermore, she has two normal sons and the investigations in her own mother, including ultrastructural studies, were normal; the extreme situation of a heterozygous state without any symptoms in either the mother or grandmother is unlikely. Thus, it is improbable that the gene has been passed down to the proband from her mother.

There have been other reports of supposedly new mutant Fabry patients. Beaudet and Caskey ${ }^{5}$ described a hemizygote as the only patient in a family, and Kobayashi et at also found a hemizygote with a clinically normal mother. In these cases, as in the present one, biochemical analyses showed normal activities of $\alpha$-gal in cells and tissues from their mothers. Full length cDNA encoding $\alpha$-galA has now been isolated, ${ }^{22}$ which has permitted studies of the molecular lesions in the gene. ${ }^{7}$ Also several informative RFLPs are now available, ${ }^{23}{ }^{24}$ so DNA based investigations of the present family would be important in order to verify the appearance of a new mutant gene and to determine the molecular nature of the defect.

The authors would like to thank Drs L S Nielsen and H Eiberg for performing the paternity tests. We gratefully acknowledge the excellent technical assistance provided by Elsebeth Lund Christensen, Minna
Becher, Anja Boesen, and Doris Nielsen. This work was supported by The Novo Foundation and The Danish Foundation for the Advancement of Medical Science.

1 Ropers HH, Wienker TF, Grimm T, Schroetter K, Bender K. Evidence for preferential $\mathrm{X}$-chromosome inactivation in a family with Fabry disease. Am f Hum Genet 1977;29:361-70.

2 Wandall A, Hasholt L, Sørensen SA. Electron microscopic observations on cultured fibroblasts from Fabry heterozygotes and hemizygotes. Ultrastruct Pathol 1982;3:51-7.

3 Avila JL, Convit J, Velazquez-Avila G. Fabry's disease: norma $\alpha$-galactosidase activity and urinary-sediment glycosphingolipid levels in two obligate heterozygotes. Br 7 Dermatol 1973;89: 149-57.

4 Rietra PJGM, Brouwer-Kelder EM, de Groot WP, Tager JM. The use of biochemical parameters for the detection of carriers of Fabry's disease. $7 \mathrm{Mol} \mathrm{Med} \mathrm{1976;1:237-55.}$

5 Beaudet AL, Caskey CT. Detection of Fabry's disease hetero zygotes by hair root analysis. Clin Genet 1978;13:251-8.

6 Kobayashi T, Shinnoh N, Kuroiwa Y. Metabolism of ceramide trihexoside in cultured skin fibroblasts from Fabry's patients, carriers and normal controls. F Neurol Sci 1984;65:169-77.

7 Desnick RJ, Bernstein HS, Astrin KH, Bishop DF. Fabry disease: molecular diagnosis of hemizygotes and heterozygotes. Enzyme 1987;38:54-64.

8 Desnick RJ, Allen KY, Desnick SJ, Raman MK, Bernlohr RW, Krivit W. Fabry's disease: enzymatic diagnosis of hemizygotes and heterozygotes. F Lab Clin Med 1973;81:157-71.

9 Lowry OH, Rosebrough NJ, Farr AL, Randall RJ. Protein measurement with the folin reagent. $f$ Biol Chem 1951;193: 265-75.

10 Hasholt L, Sørensen SA. A microtechnique for quantitative measurements of acid hydrolases in fibroblasts. Its application in diagnosis of Fabry disease and enzyme replacement studies. Clin Chim Acta 1984;142:257-61.

11 Mayes JS, Scheerer JB, Sifers RN, Donaldson ML. Differential assay for lysosomal alpha-galactosidases in human tissues and its application to Fabry's disease. Clin Chim Acta 1981;112: 247-51.

12 Goto I, Tabira T, Nawa A, Kurokawa T, Kuroiwa Y. Biochemical and genetic studies in two families with Fabry disease. Arch Neurol 1973;31:45-50.

13 Ewing DJ. Practical bedside investigation of diabetic autonomic neuropathy. In: Bannister R, ed. Autonomic failure. Oxford: Oxford University Press, 1983:371-405.

14 Persson A, Solders G. R-R variations, a test of autonomic dysfunction. Acta Neurol Scand 1983;67:285-93.

15 Desnick RJ, Sweeley CC. Fabry's disease: $\alpha$-galactosidase A deficiency. In: Stanbury JB, Wyngaarden JB, Frederickson DS, Goldstein JL, Brown MS, eds. The metabolic basis of inherited disease. New York: McGraw-Hill, 1983:906-43.

16 Bird TD, Lagunoff D. Neurological manifestations of Fabry disease in female carriers. Ann Neurol 1978;4:537-40.

17 Visser SL, de Groot WP. Electroencephalographic and electromyographic changes in a case of angiokeratoma corporis diffusum (Fabry's disease). Confin Neurol 1970;32:25-32.

18 Menzies DG, Campbell IW. Magnetic resonance imaging in Fabry's disease. F Neurol Neurosurg Psychiatry 1988;51:1240-1.

19 Cable WJL, Kolodny EH, Adams RD. Fabry disease: impaired autonomic function. Neurology (Minneap) 1982;32:498-502.

20 Roudebush CP, Foerster JM, Bing OHL. The abbreviated PR interval of Fabry's disease. N Engl F Med 1973;289:357-8.

21 Sheth KJ, Good TA, Murphy JV. Heterozygote detection in Fabry disease utilizing multiple enzyme activities. Am $\mathcal{f}$ Med Genet 1981;10:141-6.

22 Calhoun DH, Bishop DF, Bernstein HS, Quinn M, Hantzopoulos P, Desnick RJ. Fabry disease: isolation of a cDNA clone encoding human $\alpha$-galactosidase A. Proc Natl Acad Sci USA 1985;82:7364-8.

23 Astrin KH, Vlasak I, Snir Lev-ran O, Bishop DF, Desnick RJ. Linkage between $\alpha$-galactosidase and six Xq21-22 RFLPs in Fabry disease families. Am $\mathcal{Y}$ Med Genet 1988;43(suppl): 135A.

24 MacDermot KD, Morgan SH, Wilson TM. Anderson Fabry disease, a close linkage with highly polymorphic DNA markers DXS17, DXS87 and DXS88. Hum Genet 1987;77:263-6. 